\title{
Rajakarjalainen kuuntelutesti: havainnoijina suomen kielen yliopisto-opiskelijat
}

\author{
HELKA RIIONHEIMO, \\ MARJATTA PALANDER \\ Itä-Suomen yliopisto
}

Tiivistelmä. Tutkimuksessa selvitetään kansanlingvistisen kuuntelutestin avulla, miten hyvin suomalaisten yliopistojen suomen kielen opiskelijat tunnistavat Raja-Karjalan murteen. Raja-Karjalassa puhuttu karjalan kieli on vakavasti uhanalainen, eikä sitä kuule jokapäiväisessä elämässä. Testi osoittaakin, että useimmille opiskelijoille näytteen kielimuoto on vierasta. Testiin osallistuneet saivat esittää näytteen alkuperästä yhden tai useamman arvauksen. Yli puolet 337 vastaajasta sijoitti näytteen Suomen itäosiin tai itärajan tuntumaan, noin kolmasosa Savoon, viidesosa Pohjois-Suomeen ja noin kymmenesosa Kaakkois-Suomeen. Noin $15 \%$ tunnisti näytteen karjalaksi; parhaiten näytteen tunnistivat Itä-Suomen yliopiston opiskelijat. Osassa vastauksia tuotiin esille vieraan kielen vaikutus, joka yhdistettiin varsinkin venäjään. Opiskelijat kiinnittivät näytteessä huomiota erityisesti pitkien $a$ ja $\ddot{a}$-vokaalien diftongiutumiseen, suomesta poikkeaviin sibilantteihin ja affrikaattaan sekä jälkitavujen $h$ :hon ja liudentuneisiin konsonantteihin, joiden perusteella näyte pyrittiin paikantamaan. Vaikka opiskelijoiden käyttämä terminologia paljasti eroja tavallisten maallikoiden metakieleen, mukana kielen kuvauksessa oli myös paljon kansanomaisia ja arkikielisiä ilmauksia.

Avainsanat: kuuntelutesti; kansanlingvistiikka; Raja-Karjala; karjala; suomi 


\section{Tutkimuksen tausta ja tavoitteet}

Karjala on suomen läheisin sukukieli, mutta vaikka sillä on ollut jo vanhastaan puhujia myös Suomessa, se on nyky-Suomessa varsin näkymätön ja kuulumaton kielimuoto. Kieli on vakavasti uhanalainen (Sarhimaa 2016); arviot karjalan kielen puhujien määrästä Suomessa vaihtelevat välillä 5 000-11 000 (Laakso ym. 2016: 107-108; Sarhimaa 2016: 3). Karjalaa ei juuri kuule käytettävän arkipäivän julkisissa tilanteissa, esimerkiksi kaupungilla liikuttaessa, vaikka monia uusia vähemmistökieliä kuten venäjää tai viroa kuulee usein vastaavissa tilanteissa. Suomen karjalankieliset ovat kaksikielisiä ja tottuneet käyttämään suomea ollessaan tekemisissä suomenkielisten kanssa. Karjalaa käytetään kotiympäristössä perheen ja sukulaisten kesken (Jeskanen 2005: 240-241; Sarhimaa 2016: 167-169). Useimmat nuoret suomalaiset eivät ole ehkä koskaan elämänsä aikana kuulleet karjalan kieltä. Tässä tutkimuksessa raportoitu kuuntelutesti pohjautuukin ennakkokäsitykseen, jonka mukaan nykysuomalaiset eivät kovin hyvin tunne karjalan kieltä eivätkä välttämättä pysty erottamaan sitä suomen murteista.

Mielikuvia ja käsityksiä kielestä ja kielimuodoista on viime vuosikymmeninä selvitetty erityisesti kansanlingvistisessä tutkimussuuntauksessa, jonka kohteena ovat ei-kielitieteilijät, siis tavalliset kielenkäyttäjät eli maallikot (suuntauksesta ks. esim. Niedzielski \& Preston 2000: 1-32; Palander 2001; Mielikäinen \& Palander 2002; Vaattovaara 2005). Tähänastisten kansanlingvististen tutkimusten mukaan suomalaisilla, varsinkin nuorilla, on varsin epämääräinen käsitys karjalasta. Koska ei-kielitieteilijöille on ominaista nimetä suomen murteita maakuntien ja muutamien kaupunkien mukaan, Karjalan murteiksi kutsutaan tyypillisesti Suomen Etelä- tai Pohjois-Karjalan maakunnissa puhuttavia murteita eli kaakkoismurteita ja itäisiä savolaismurteita. Nimityksellä voidaan viitata myös yhteisesti kumpaankin alueeseen. Lisäksi Karjalan murteilla voidaan tarkoittaa Karjalankannaksella puhuttuja kaakkoismurteita tai Karjalan tasavallassa puhuttua karjalan kieltä. Rajantakainen Karjala yhdistyy kuitenkin nykyään vain harvoin ei-lingvistien karjalaan; siitä 
ovat tietoisimpia itäsuomalaiset ja etenkin ne, joilla on omia sukujuuria luovutetun Karjalan alueella. (Palander \& Nupponen 2005; Mielikäinen \& Palander 2014b: 65; Palander 2015: 41-42)

Tämä artikkeli perustuu kuuntelutestiin, jossa karjalankielinen äänitekatkelma on soitettu eri yliopistojen suomen kielen perus- ja aineopintovaiheen opiskelijoille. Testi on noudattanut kansanlingvistiikan metodeja, mutta kohderyhmänä eivät ole olleet varsinaiset ei-kielitieteilijät vaan opiskelijat eli valikoitunut joukko, jolla on jonkin verran kielitieteellistä tietoa ja koulutusta ja jotka ovat opiskelupaikan valintansa vuoksi kenties keskimääräistä herkempiä havainnoimaan kielellisiä ilmiöitä. Useimmat eivät kuitenkaan olleet testivaiheessa tarkemmin tutustuneet opinnoissaan karjalan kieleen. Aiemmin on käynyt ilmi, että vastaavassa vaiheessa olevilla suomen kielen yliopisto-opiskelijoilla on vaikeuksia kuulonvaraisesti paikantaa myös äidinkielensä suomen aluemurteita (Palander \& Nupponen 2005: 42-45).

Kuuntelutestin päätavoitteena oli vastata seuraaviin kysymyksiin:

1) Miten eri puolilla Suomea asuvat, opintojensa alkuvaiheessa olevat suomen kielen yliopisto-opiskelijat tunnistavat Raja-Karjalan murteen? Onko opiskelijan omalla murretaustalla merkitystä tunnistamistehtävässä?

2) Mihin opiskelijat perustavat päätelmänsä? Mihin kielenpiirteisiin he kiinnittävät näytteessä huomiota?

3) Miten opiskelijoiden saama suomen kielen yliopistokoulutus vaikuttaa vastauksiin? Eroavatko perusopintovaiheen opiskelijoiden vastaukset aineopintovaiheessa olevien vastauksista? Onko eri yliopistojen opiskelijoiden välillä eroa? Poikkeavatko testin tulokset aiemmista tutkimuksista, joissa tutkittavana ovat olleet varsinaiset ei-kielitieteilijät?

Artikkeli etenee seuraavasti: luvussa 2 esitellään kuuntelutesti ja testiin osallistuneet informantit. Luku 3 käsittelee kielennäytteen paikantamista ja informanttien taustan vaikutusta siihen. Luvussa 4 tarkastellaan, millaisten kielenpiirteiden perusteella näyte on paikannettu, ja artikkelin päättävä luku 5 kokoaa tutkimuksen tulokset. 


\section{Kuuntelutesti ja informantit}

Kuuntelutestejä on käytetty kansanlingvistiikassa jo 1980-luvulta saakka tutkittaessa alueellisten varieteettien tunnistusta ja niitä kielenpiirteitä, joiden perusteella varieteetteja erotellaan. Testeissä on sovellettu esimerkiksi sellaista asetelmaa, että koehenkilöitä on pyydetty yhdistämään kuulemansa näytteet annettuihin alueisiin (Niedzielski \& Preston 2000: 82-95; Mikkola 2011). Toisissa koeasetelmissa kuulijat ovat saaneet määrittää näytteiden alueellisen taustan ilman tarkempia vihjeitä (Palander \& Nupponen 2005; Vaattovaara 2009: 136-143; 2013; Kokko 2010; Nupponen 2011; Vilhula 2012). Kokeellis-foneettisilla kuuntelutesteillä on selvitetty mm. sitä, kuinka paljon varieteettiin liittyvät ennakkoasenteet vaikuttavat kielenpiirteen havaitsemiseen (Niedzielski 1999; Vaattovaara 2013). Kuuntelutestien avulla on tutkittu myös, millaisia mielikuvia näytteessä kuultu kieli herättää (esim. Laurila 2008; Saaristo 2015).

Tässä tutkimuksessa kuuntelutestin avulla selvitetään sitä, mihin maantieteelliseen alueeseen ja kielimuotoon informantit yhdistävät rajakarjalaisen kielennäytteen, ja sitä, millainen on yksittäisten kielenpiirteiden vaikutus kielennäytteen sijoittamisessa. Karjalan kielen RajaKarjalan murteita on viime sotiin asti puhuttu Suomeen vielä tuolloin kuuluneissa Suojärven, Korpiselän, Suistamon, Soanlahden, Impilahden ja Salmin kunnissa sekä Ilomantsin itäisimmissä kylissä (kartta 1). Vuonna 1944 Suomi menetti nämä alueet Neuvostoliitolle, ja alueen asukkaat siirrettiin muualle Suomeen, pääasiassa Pohjois-Karjalaan, Pohjois-Savoon ja Oulun seudulle. Valtaosa rajakarjalaisista puhui karjalan kieltä eli varsinaiskarjalan etelämurteita tai livvinkarjalaa, mutta uusilla asuinpaikoilla karjalan kieli alkoi vähitellen sulautua suomen murteisiin. (Jeskanen 2005: 238-242; Pyöli 2013: 172-174.)

Raja-Karjalan kuuntelutestin näytteenä oli noin puolentoista minuutin mittainen katkelma haastattelusta, jossa puhuu Porajärvellä vuonna 1900 syntynyt nainen. Puhujan syntymäpaikka on sijainnut eteläkarjalan murrealueella ja rajautunut Ilomantsin rajakarjalaiskyliin. Puhuja on elänyt Porajärvellä 17 -vuotiaaksi, minkä jälkeen hän on mennyt 
naimisiin Ilomantsin Liusvaaraan. (Ks. karttaa 1.) Kun alue menetettiin Neuvostoliitolle 1944, perhe muutti nykyiseen Ilomantsiin. Näyte on tallennettu vuonna 1975, jolloin puhuja oli 74 -vuotias.

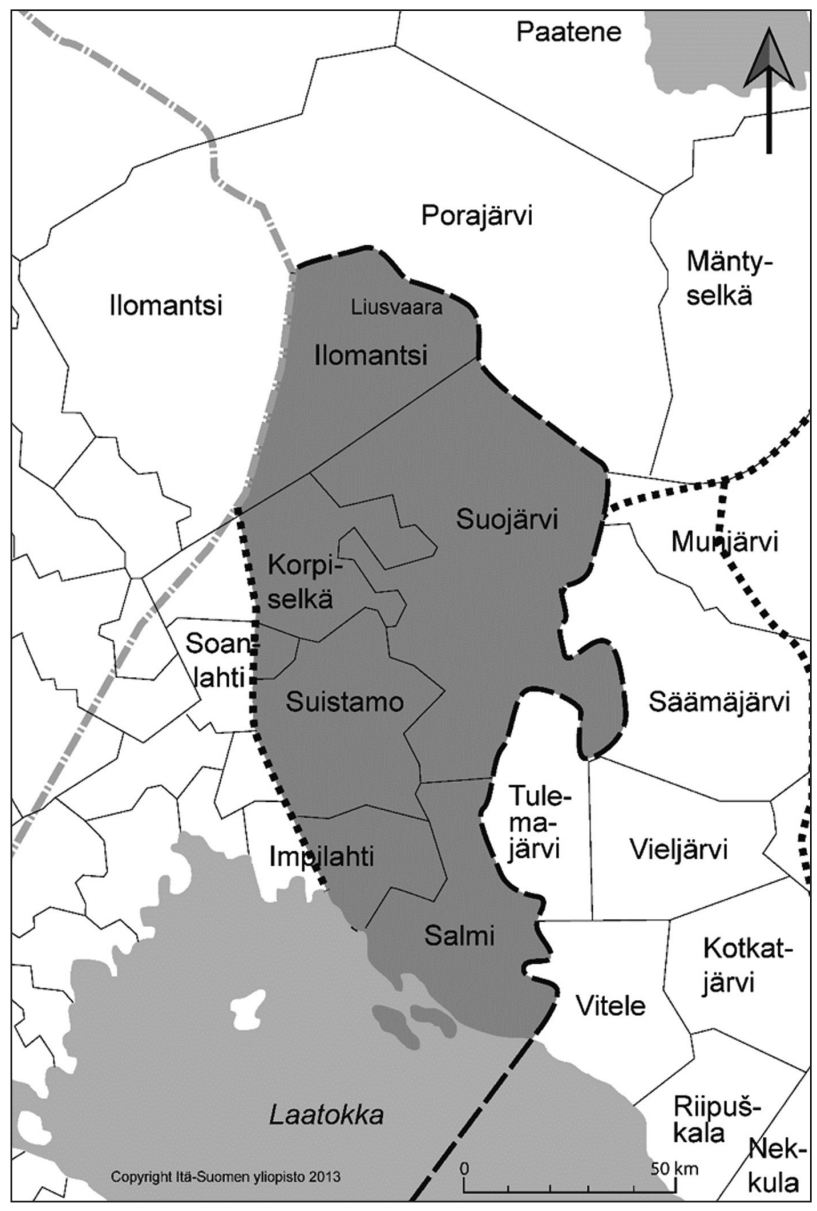

KARTTA 1. Raja-Karjalan murteet. Alue on merkitty harmaalla.

Kartasta näkyvät myös kielennäytteen puhujan syntymäpitäjä

Porajärvi, naimisiin menon jälkeinen kotikylä Liusvaara

Ilomantsissa sekä nykyisen Ilomantsin alue 
Kielennäytteessä haastateltava puhuu varsinaiskarjalan etelämurretta, joskin puheessa esiintyy jonkin verran myös suomen kielen vaikutusta (suomen ja rajakarjalaismurteiden kontaktista ks. esim. Turunen 1982; Koivisto tulossa). Katkelma on esitetty karkeasti litteroituna alla. Se sisältää lukuisia karjalan kielelle ominaisia mutta suomesta (varsinkin yleiskielestä tai länsimurteista) poikkeavia kielenpiirteitä. Äänteellisiä erityispiirteitä ovat esimerkiksi soinnilliset tai puolisoinnilliset klusiilit (kumba, isändä, pidi), liudennus (ńimi, t'ietäjä, ol'), suhu-s (tuošša), affrikaatta (iče), konsonanttiyhtymien st ja sk astevaihtelu (muissa, kässe) sekä $A A: n$ diftongiutuminen ensitavussa (hoaššettih, piässä) ja jälkitavuissa (pahempoa) sekä loppukahdennuksen puuttuminen. Morfologisia karjalan kielelle ominaisia piirteitä ovat muun muassa liitepartikkeli - $i$ (mitäi), NUT-partisiipin $t$-variantti (tahtot, varastat), suomen $V n$-päätettä vastaava $h$ esimerkiksi passiivissa (käytih, sanottih; ns. vokaalienvälinen $h$ ) ja loi-monikko (kärrilöil). Karjalankielistä sanastoa puolestaan edustavat konjunktio ta 'ja' ja pronomini mi 'mikä.

kumba minä niitä en lapšuuvesta muissa. ne ol' pitkäm matkam piässä mit ol'i ne kuulu. niitä piti lähtie nää-kärrilöil_ajettii hevosila monet monet, kyläv välit. kun käytih. ja tuošša on yksi, Kivilahessa yks Kärkkäine ol'i. mikäs sillä ńimi, olis ku Kärkkäiseksi vaan sanottih minä nyt em muišša mikä sillä ńimi on ei se on vasta äskettäin kuollut. ni se ol'i semmońi kuulema t'ietäjä, jos varasti, toine minkä, ja järkieh mäni sanomah, häneltä hävisi ja se voi varaštoa, pitäis olla semmońi semmońi hänem mielem mukah ńin, kuuleh se teki sen ei käynyt missäi ja se toi sen iče. käynyt ei minnee paikam piältä mikäv, hänellä lie ollut semmońi. šitähän Kivilahessa ho- hoaššettih ihan julki jälki. ta käypi moń on käynyt sen luokše. oisko rahakukkaron tahi mi humalas varastat kuka ńi se pidi tuuva takaši. ta anteeksi pyyvellä. šit_ei tullut mitäi. jos ois tahtot se, isändä sen, keltä varasti minkä nin, se ois tehnyt niin kun vähä mitä hyvää, pahempoa. va s_ei kuka se sitä va eihän kukai, šemmoišta. kässe tehä.

Kuuntelutestissä informantit saivat täytettäväkseen kyselylomakkeen. Lomakkeessa kysyttiin ensiksi vastaajan taustatiedot eli syntymävuosi, sukupuoli, syntymäkotikunta ja kotimurre. Varsinaisia testikysymyksiä 
oli kolme: 1) mistä päin näytteen puhuja oli kotoisin, 2) mitä kielimuotoa (kieltä, murretta tms.) hän puhui ja 3) miten hänen puheensa erosi vastaajalle tutusta arkipuhekielestä. Viimemainitun kysymyksen yhteydessä kehotettiin merkitsemään muotoja, joissa tällaisia eroja ilmeni. Kaikki testikysymykset olivat ns. avokysymyksiä. Testinäyte kuuntelutettiin kahteen kertaan, jotta informanteilla oli parempi mahdollisuus tehdä havaintoja.

Testiin osallistui yhteensä 337 äidinkieleltään suomenkielistä suomen kielen opiskelijaa Helsingin, Itä-Suomen, Jyväskylän, Oulun, Tampereen ja Turun yliopistoissa vuosien 2013-2016 aikana. Perusopintovaiheen opiskelijoita oli 207 ja aineopintovaiheen opiskelijoita 130. Kaikki osallistujaryhmät olivat heterogeenisia, sillä joukossa oli myös suomen kielen sivuaineopiskelijoita, joilla oli takanaan vaihteleva määrä yliopisto-opintoja (usein jonkin vieraan kielen opintoja). Informanttien murretaustat vaihtelivat: itämurteiden alueelta oli kotoisin 123, länsimurteiden alueelta 147 ja pohjoisesta 57 opiskelijaa. Nuorin osallistujista oli syntynyt vuonna 1997 ja vanhin vuonna 1956, mutta ikäjakauma painottui vahvasti nuoriin ikäluokkiin: 1960-luvulla syntyneitä oli 4, 1970-luvulla syntyneitä 11, 1980-luvulla syntyneitä 52 ja 1990-luvulla syntyneitä 269 . Sukupuolijakaumassa naiset olivat suuri enemmistö: naisia oli 288 , miehiä 47, ja yksi ei merkinnyt sukupuoltaan.

\section{Kielennäytteen paikantaminen}

Kyselylomakkeessa tiedusteltiin, mistä päin näytteen puhuja oli kotoisin, sekä mitä kielimuotoa hän puhui. Olemme käsitelleet puhujan taustaa koskevia vastauksia ottamalla huomioon sekä opiskelijan tarjoaman alueen tai paikkakunnan että tarjotun kielimuodon nimen, sillä ei-kielitieteilijöiden metakielessä nämä kietoutuvat usein yhteen (ks. Mielikäinen \& Palander 2014b: 49-53). Opiskelijoiden käyttämä metakieli vaihteli, ja aluemurteiden nimet olivat usein kansanomaisia, mikä vaikeutti osin vastausten tulkintaa. Aineiston tulkinnassa onkin otettu huomioon se, mitä aiemman tutkimuksen perusteella tiedetään suomalaisten murteita 
koskevasta metakielestä (Mielikäinen \& Palander 2014b). Taulukoissa tulokset on esitetty frekvensseinä (f) ja prosentteina suhteessa vastaajien yhteismäärään $(\mathrm{N}=337)$, mutta tulosten kvantifioinnissa on huomattava, että sama vastaaja saattoi esittää näihin kohtiin useita arvauksia, ja osa taas jätti eräisiin kysymyksiin kokonaan vastaamatta. Tilastolliset merkitsevyydet on laskettu suhteessa vastausten (ei vastaajien) määrään.

\subsection{Arviot näytteen edustamasta alueesta}

Opiskelijoiden antamat arviot kielennäytteen puhujan alueellisesta taustasta ja kielimuodosta on analyysissa ryhmitelty 13 luokkaan. Vastauksista hahmottuvat ilmansuuntien mukaan nimetyt luokat "itä", "pohjoinen", "kaakko", "lounas" ja "länsi” sekä maakuntamurteisiin viittaavat "Savo", "Kainuu", "Häme", "Keski-Suomi" ja "Pohjanmaa". "Karjalan kieli" on omana luokkanaan. Näiden lisäksi testissä annettiin muutamia vastauksia, jotka on sijoitettu luokkiin "muu" ja "ei vastausta". Taulukkoon 1 on koottu vastausten jakauma suhteessa vastaajien yhteismäärään. Seuraavat esimerkit havainnollistavat vastausten luokittelua:

(1) [Mistä puhuja on kotoisin?] Veikkaisin, että jostain Itä-Suomesta. Ei ihan ytimestä, mutta reunoilta.

[Mitä kielimuotoa hän puhuu?] Osittain sanoista "piällä" ja "huastettu" tulee mieleen Savon murre, mutta muutoin murre ei aivan kuulosta savolaiselta. Jotain pohjoista, lappilaista puheessa vilahtelee myös.

Esimerkin (1) vastaukset on tulkittu alueellisesti edustamaan "itää", "pohjoista" ja "Savoa", eli yhden vastaajan arvaukset jakaantuvat kolmeen luokkaan.

(2) [Mistä?] Karjalasta? Alunperin (kuuluu pieniä kaikuja, kuten suhu-s ja äng-äännettä), nykyisin voisi asua esim. Ilomantsissa tai muualla ItäSuomessa.

[Mitä kielimuotoa puhuu?] Karjalan murretta (siis pohjoiskarjalaista).

Esimerkissä (2) puolestaan Karjalalla viitataan mitä ilmeisimmin karjalan kielen alueeseen (mainitaan suhu-s ja oletus nykyisestä 
asuinpaikasta), mutta toisaalta nimitys Karjalan murre täsmennettynä pohjoiskarjalaiseksi kytkee arvauksen Pohjois-Karjalan maakuntaan. Näillä perusteilla vastaukset on luokiteltu edustamaan "karjalan kieltä" ja "itää” (“idän” luokittelusta tarkemmin alempana).

Taulukко 1. Arviot puhujan alueellisesta taustasta suhteessa vastaajien kokonaismäärään (337)

\begin{tabular}{|l|c|c|}
\hline Luokka & f & Prosentti \\
\hline Itä & 213 & $63,2 \%$ \\
\hline Savo & 103 & $30,6 \%$ \\
\hline Pohjoinen & 77 & $22,8 \%$ \\
\hline Karjalan kieli & 52 & $15,4 \%$ \\
\hline Kaakko & 30 & $8,9 \%$ \\
\hline Kainuu & 14 & $4,2 \%$ \\
\hline Häme & 12 & $3,6 \%$ \\
\hline Keski-Suomi & 11 & $3,3 \%$ \\
\hline Lounas & 5 & $1,5 \%$ \\
\hline Pohjanmaa & 4 & $1,2 \%$ \\
\hline Länsi & 3 & $0,9 \%$ \\
\hline Muu & 6 & $1,8 \%$ \\
\hline Ei vastausta & 6 & $1,8 \%$ \\
\hline Yhteensä & 534 & \\
\hline
\end{tabular}

Selvästi eniten vastauksia (runsaat $63 \%$ ) sijoittuu luokkaan, jonka olemme nimenneet suurpiirteiseksi “idäksi”. Tähän sisältyvät sellaiset vastaukset, joissa mainitaan ilmansuunta itä tai sijainti Suomen itärajalla, esimerkiksi Itä-Suomi, itäraja, jokin itäinen kaupunki, Venäjän raja, Suomen ja Venäjän rajaseutu, enemmän idästä kuin lännestä. Kielimuotoina mainittiin mm. itäsuomalainen murre ja itämurre. Tähän luokkaan on laskettu mukaan myös sellaiset maininnat kuin Karjala ja PohjoisKarjala tai karjala, karjalan murre silloin kun ei ole ollut varmaa, tarkoittiko vastaaja suomen murteita vai erillistä karjalan kieltä. On myös syytä huomata, että tässä luokassa eivät ole mukana ne vastaukset, joissa 
viitataan Kainuun alueeseen, sillä Kainuun monet mieltävät enemmän pohjoiseksi kuin itäiseksi (Palander 2011: 110-112). Lisäksi KaakkoisSuomeen viittaavia vastauksia on käsitelty omana luokkanaan.

Toiseksi yleisimmin vastaukset yhdistyivät täsmällisemmin "Savoon" (noin 30 \%:lla vastaajista). "Savoa" on analyysissa pidetty erillisenä, "idästä" erotettuna luokkana, sillä kaikkia savolaismurteita ei puhuta Itä-Suomessa. "Savoksi" on analyysissa laskettu kaikki ne tapaukset, joissa on mainittu paikannimi Savo tai tarkemmin Etelä- tai PohjoisSavo tai joissa viitataan sellaisiin kielimuotoihin kuin savon murre, savo, savolainen karjalan murre tai itäinen savolaismurre. Lisäksi mukana ovat vastaukset, joissa mainittiin savolaisalueella sijaitseva paikannimi, yleisimmin Kuopio.

Kolmanneksi suurimman luokan muodostavat yllättäen ne vastaukset, jotka liittyvät tavalla tai toisella "pohjoiseen" (lähes 23 \%:lla opiskelijoista). Tähän ryhmään sisältyvät sellaiset vastaukset, joissa viitataan pohjoiseen ilmansuuntaan (esim. pohjoinen, pohjoinen Suomi, PohjoisSuomi, Pohjois-Pohjanmaa, pohjoinen Länsi-Suomi), Lappiin (Lappi, käsivarren tienoo, Pohjoinen Lappi, Koillis-Lappi, Lapin perukka) tai tiettyihin Lapin paikannimiin (Rovaniemi, Tornio, Tornionjokilaakso, Pello, Enontekiö). Kielimuodoista mainittiin mm. Lapin murre, Peräpohjolan murre, pohjoismurteet, pohjoispohjalainen murre, jänhkä ja meänkieli. Kun kolmannessa tehtävässä pyydettiin merkitsemään muistiin muotoja ja kielenpiirteitä, moni tähän ryhmän vastaajista nosti esiin $h$-kirjaimen, ja karjalan kielelle ominainen sananloppuinen $h$ on ilmeisesti luonut pohjoista vaikutelmaa (ks. lukua 4.4). Lisäksi vastauksiin on voinut vaikuttaa näytteen sisältö, jossa mainitaan sana tietäjä; yksi vastaaja onkin perustellut, että tämä "teema viittaa Lappiin" (puheenaiheen vaikutuksesta tunnistustesteissä ks. Nupponen 2011: 82, 149, 253).

Neljänneksi suurin vastausryhmä on "karjalan kieli", jonka tunnisti näytteestä noin $15 \%$ opiskelijoista. Vastausten ryhmittely tähän luokkaan vaati tarkkaa harkintaa, sillä pelkästä karjalasta ei voi päätellä, mitä vastaaja on nimityksellä tarkoittanut. Kansanomaisia nimityksiä karjala ja karjalan murre käytetään nimittäin vaihtelevasti Suomen Etelä- ja 
Pohjois-Karjalan maakuntien puhekielestä sekä luovutetun alueen kaakkoismurteista ja karjalan kielestä (Palander \& Nupponen 2005: 16-22). Muutamat epävarmat vastaukset onkin sijoitettu pelkästään luokkaan "itä" (eikä luokkaan "karjalan kieli"). Tulkinnassa on otettu huomioon myös ne kielenpiirteet, joita vastaajat ovat kirjanneet; esimerkiksi maininnat erilaisista $s$-äänteistä, liudennuksesta tai venäjää muistuttavasta ääntämisestä (ks. lukua 4.3) viittaavat suomen sijasta karjalan kieleen. Tässä luokassa puhujan oletettua kotipaikkaa nimitettiin esimerkiksi rajantakaiseksi Karjalaksi, Venäjän Karjalaksi tai Raja-Karjalaksi ja kielimuotoa arveltiin karjalan lisäksi vanhaksi karjalaksi, vienankarjalaksi tai venäjänkarjalaksi. Muutaman kerran viitattiin selvästi suomen sukukieleen: puhujan sanottiin puhuvan suomen kaltaista karjalan kieltä tai suomea lähellä olevaa suomensukuista kieltä.

Viidenneksi yleisin luokka ovat ilmansuuntaan "kaakko" liittyvät arvaukset, joita esitti noin $9 \%$ testiin osallistuneista. "Kaakko" on luokittelussa erotettu "idästä", koska sillä ilmansuunnalla maallikot viittaavat yleensä juuri kaakkoismurteiden alueeseen (Palander 2011: 124). Luokkaan on ryhmitelty ne vastaukset, joissa mainitaan esimerkiksi Kaakkois-Suomi, Etelä-Karjala, Laatokan-Karjala, Karjalan kannas, jokin kaakkoissuomalainen kaupunki (Viipuri, Imatra) tai luovutettu alue tai luovutettu Karjala (joka on tosin kaksitulkintainen, mikäli sillä ymmärretään Karjalankannaksen lisäksi Raja-Karjalaakin). Kielimuodon nimityksistä Kaakkois-Suomen murre, kaakkoismurre, Etelä-Karjalan murre, kaakkoinen itämurre ja myös Inkerin murre kuuluvat tähän luokkaan.

Muut alueet olivat vastauksissa harvemmin edustettuina. "Kainuuseen" (joka sisältää tässä myös Koillismaan) näytteen puhujan sijoitti noin $4 \%$ vastaajista. Mielikuva Kainuusta liittyy aineiston perusteella pohjoiseen, sillä maakunnan nimi yhdistetään vastauksissa PohjoisSuomeen (jostain Savon ja Lapin rajoilta? Kainuusta?; Pohjois-Suomesta, Kainuusta), ja tällä perusteella "Kainuun" olisi voinut niputtaa samaan luokkaan "pohjoisen" kanssa. "Häme" esiintyi lähes 4 \%:lla ja "KeskiSuomi" noin $3 \%: 1 l a$ opiskelijoita. "Lounaaseen" liittyviä vastauksia (esim. Turun seutu, lounaismurre) antoi noin 1,5\% vastaajista. "Pohjanmaata" 
ehdotti runsas prosentti, ja tähän luokkaan laskettiin sekä nimitys Pohjanmaa että tarkkarajaisempi Etelä-Pohjanmaa; Pohjanmaalla maallikot tarkoittavat yleisesti nimenomaan Etelä-Pohjanmaata (Mielikäinen \& Palander 2014b: 64). Noin 1 \% vastaajista arveli puhujan olevan "lännestä” (Länsi-Suomesta, Suomen länsiosasta). Lisäksi testissä annettiin yksittäisiä muita vastauksia (esim. viro, Koillis-Suomi, raja tai näytteessä mainittu paikannimi Kivilahti), ja kuusi opiskelijaa jätti kyseisiin kohtiin kokonaan vastaamatta.

Taulukon 1 laskelmat osoittavat, että enemmistö opiskelijoista tunnisti näytteen itäiseksi, mutta vain noin $15 \%$ päätyi vastauksessaan karjalan kieleen. Lisäksi yllättävän moni vastaaja piti kielennäytettä pohjoissuomalaisena (noin $23 \%$ ). Seuraavassa luvussa selvitämme, missä määrin vastaajan tausta on vaikuttanut arvauksiin.

\subsection{Vastaajan alueellisen taustan vaikutus arvioihin}

Kyselylomakkeessa vastaajia pyydettiin merkitsemään syntymäkotikuntansa sekä kotimurteensa. Näiden taustatietojen perusteella opiskelijat on ensin ryhmitelty maakunnittain ja murreryhmittäin, ja näiden mukaisesti heidät on edelleen jaoteltu edustamaan itä-, länsi- ja pohjoismurteita. Itämurteisiin on luettu savolaismurteet, lukuun ottamatta Kainuun murteita, sekä kaakkoismurteet. Länsimurteita edustavat puolestaan lounais-, hämäläis- ja eteläpohjalaismurteet. Pohjoismurteisiin on luokiteltu Kainuun murteet, keski- ja pohjoispohjalaiset murteet sekä peräpohjalaismurteet. Jaottelu noudattaa osin Paunosen (1991 ja 2006: 255, 268) ja Leinon, Hyvösen ja Salmenkiven (2006) ehdottamaa suomen murteiden jakoa kolmeen pääryhmään.

Taulukosta 2 ilmenee testivastausten jakauma vastaajien murretaus$\tan$ mukaan. Huomioon on otettu taulukon 1 viisi suurinta ryhmää, mutta ne on järjestetty siten, että itäiset kielimuodot on mainittu ensin ja "pohjoinen" on taulukossa viimeisenä. 
TAULUкко 2. Paikannukset suhteessa vastaajien murretaustaan

\begin{tabular}{|l|c|c|c|c|c|c|c|c|c|c|c|}
\hline \multirow{2}{*}{ Murretausta } & \multicolumn{2}{|c|}{ Itä } & \multicolumn{2}{|c|}{ Savo } & \multicolumn{2}{c|}{$\begin{array}{c}\text { Karjalan } \\
\text { kieli }\end{array}$} & \multicolumn{2}{c|}{ Kaakko } & \multicolumn{2}{c|}{$\begin{array}{c}\text { Pohjoi- } \\
\text { nen }\end{array}$} & $\begin{array}{c}\text { Vas- } \\
\text { taajia }\end{array}$ \\
\cline { 2 - 13 } & f & \% & f & \% & f & \% & f & \% & f & \% & N \\
\hline Itämurt. & 82 & 68 & 44 & 36 & 26 & 21 & 17 & 14 & 28 & 23 & 123 \\
\hline Länsimurt. & 97 & 62 & 33 & 21 & 21 & 13 & 9 & 6 & 42 & 27 & 157 \\
\hline Pohjoismurt. & 34 & 60 & 26 & 46 & 5 & 9 & 4 & 7 & 7 & 12 & 57 \\
\hline Yhteensä & 213 & & 103 & & 52 & & 30 & & 77 & & 337 \\
\hline
\end{tabular}

Vastaajia oli eniten länsimurteiden ryhmästä, 157. Itämurteiden edustajia oli 123 ja pohjoismurteiden 57. Murretausta ei aiheuttanut merkitseviä eroja näytteen puhujan sijoittamisessa "itään" $\left(\chi^{2}\right.$-testissä $\left.p=0,438\right)$, vaikkakin suhteellisesti eniten näitä vastauksia oli itämurteiden edustajilla (67,5 \%). Myöskään luokkiin "kaakko" ( $\mathrm{p}=0,211)$ ja "karjalan kieli" $(\mathrm{p}=0,276)$ sijoittaminen ei ole tilastollisesti riippuvainen vastaajan murretaustasta, vaikka itämurteisten vastausten prosenttiosuudet ovat näissäkin suurimmat. Sen sijaan paikannusluokassa "Savo" erot ovat erittäin merkitseviä ( $\mathrm{p}<0,01)$ : pohjoismurretaustaisista jopa $46 \%$ piti näytettä savolaismurteisena. Myös luokassa "pohjoinen" erot ovat merkitseviä $(\mathrm{p}<0,05)$, sillä erityisesti länsimurteiset vastaajat arvelivat näytteen edustavan pohjoismurteita.

Tuloksia voidaan tarkastella myös siltä kannalta, mistä yliopistosta vastaajat olivat. Yliopistot saavat opiskelija-aineksensa paljolti ympäröivistä maakunnista; kuitenkin Helsingin yliopistoon hakeutuu runsaasti opiskelijoita oman lähialueen ulkopuolelta. Yliopistojen profilaatiokin voi vaikuttaa testituloksissa. Taulukkoon 3 paikannukset on ryhmitelty yliopistojen mukaan.

"Itä"-paikannuksissa ei ole suuria eroja yliopistojen välillä; Turun ja Itä-Suomen yliopistojen luvut poikkeavat muista vähäisempinä, mutta erot eivät ole tilastollisesti merkitseviä ( $p>0,05)$. "Savo"-paikannuksia on suhteellisesti eniten Jyväskylän yliopiston opiskelijoilla, mutta tässäkään luokassa erot eivät ole merkitseviä. Yliopistojen erot ovat selvemmät luokissa "pohjoinen" ja "karjalan kieli": pohjoismurteisena näytettä pitivät etenkin Tampereen yliopiston edustajat ja karjalankielisenä 
erityisesti Itä-Suomen yliopiston opiskelijat, mikä aiheuttaa erojen merkitsevyyden $(\mathrm{p}<0,05)$. Tilastollisesti erittäin merkitsevä ero $(\mathrm{p}<0,01)$ on luokkaan "kaakko" sijoittuvissa vastauksissa: niitä antoivat eniten Jyväskylän yliopiston opiskelijat.

TAULUкко 3. Paikannukset suhteessa vastaajien yliopistotaustaan

\begin{tabular}{|l|c|c|c|c|r|r|r|r|r|r|c|}
\hline \multirow{2}{*}{ Yliopisto } & \multicolumn{2}{|c|}{ Itä } & \multicolumn{2}{|c|}{ Savo } & \multicolumn{2}{|c|}{$\begin{array}{c}\text { Karjalan } \\
\text { kieli }\end{array}$} & \multicolumn{2}{|c|}{ Kaakko } & \multicolumn{2}{c|}{$\begin{array}{c}\text { Pohjoi- } \\
\text { nen }\end{array}$} & $\begin{array}{c}\text { Vas- } \\
\text { taajia }\end{array}$ \\
\cline { 2 - 13 } & f & \% & f & \% & f & \% & f & \% & f & \% & \multicolumn{1}{c|}{ N } \\
\hline Helsingin yliopisto & 22 & 65 & 8 & 24 & 3 & 9 & 3 & 9 & 9 & 26 & 34 \\
\hline Itä-Suomen yliopisto & 56 & 60 & 29 & 31 & 26 & 28 & 8 & 9 & 25 & 27 & 94 \\
\hline Jyväskylän yliopisto & 20 & 65 & 14 & 45 & 1 & 3 & 13 & 42 & 3 & 10 & 31 \\
\hline Oulun yliopisto & 22 & 65 & 14 & 41 & 3 & 9 & 1 & 3 & 2 & 6 & 34 \\
\hline Tampereen yliopisto & 72 & 68 & 25 & 24 & 14 & 13 & 2 & 2 & 31 & 29 & 106 \\
\hline Turun yliopisto & 21 & 55 & 13 & 34 & 5 & 13 & 3 & 8 & 7 & 18 & 38 \\
\hline Yhteensä & 213 & & 103 & & 52 & & 30 & & 77 & & 337 \\
\hline
\end{tabular}

Se että karjalan kieli oli tutuinta Itä-Suomen yliopiston opiskelijoille, ei sinänsä yllätä. Itä-Suomen yliopistossa karjalan kieli on ollut näkyvästi esillä vuodesta 2009 lähtien, jolloin perustettiin karjalan kielen ja kulttuurin professuuri ja karjalan opetus sivuaineena aloitettiin. Vaikka karjalan kieli ei yleensä kuulu suomen kielen opiskelijoiden ensimmäisen vuoden ohjelmaan, tietoa oppiaineesta on saatavilla opintojen alusta lähtien. Tulokseen vaikuttanee osaltaan myös se, että useilla itäsuomalaisilla on sukujuuria Raja-Karjalassa.

Selvästi alueesta johtuu myös se, että Oulun yliopiston opiskelijoista vain $6 \%$ sijoitti näytteen pohjoissuomalaisten murteiden alueelle. Muiden yliopistojen ryhmissä "pohjoisen" arviot vaihtelivat 10-29\%. Pohjalaisten ja peräpohjalaisten murteiden voi olettaa olevan Oulun seudulla asuville niin tuttuja, ettei karjalankielistä näytettä sekoiteta niihin. 


\subsection{Opintojen vaiheen vaikutus arvioihin}

Kuuntelutestiin osallistui sekä perusopinto- että aineopintovaiheen opiskelijoita. Enemmistö, noin 60 \%, oli vasta aloittamassa suomen kielen opintojaan, joskin suomen sivuaineopiskelijoilla oli usein takanaan vaihteleva määrä jonkin muun kieliaineen yliopisto-opintoja. Aineopintovaiheen osallistujat olivat opiskelleet ainakin vuoden ajan suomen kieltä, mihin on kuulunut myös suomen murteisiin liittyviä opintoja. Taulukossa 4 testitulokset on ryhmitelty opintovaiheen mukaan; mukana ovat jälleen taulukon 1 viisi suurinta ryhmää.

TAULuкко 4. Paikannukset suhteessa vastaajien opintojen vaiheeseen

\begin{tabular}{|l|r|c|c|c|c|c|c|c|c|c|c|}
\hline \multirow{2}{*}{ Vuosikurssi } & \multicolumn{2}{|c|}{ Itä } & \multicolumn{2}{|c|}{ Savo } & \multicolumn{2}{c|}{$\begin{array}{c}\text { Karjalan } \\
\text { kieli }\end{array}$} & \multicolumn{2}{c|}{ Kaakko } & \multicolumn{2}{c|}{$\begin{array}{c}\text { Pohjoi- } \\
\text { nen }\end{array}$} & Vastaajia \\
\cline { 2 - 13 } & \multicolumn{1}{|c|}{ f } & \% & f & \% & f & \% & f & \% & f & $\%$ & N \\
\hline Perusopinnot & 133 & 64 & 65 & 31 & 34 & 16 & 19 & 9 & 44 & 21 & 207 \\
\hline Aineopinnot & 80 & 62 & 38 & 29 & 18 & 14 & 11 & 8 & 33 & 25 & 130 \\
\hline Yhteensä & 213 & & 103 & & 52 & & 30 & & 77 & & 337 \\
\hline
\end{tabular}

Odotusten vastaisesti erot perus- ja aineopintovaiheen opiskelijoiden välillä ovat pieniä, paikannusryhmittäin yleensä vain muutaman prosenttiyksikön suuruisia, eivätkä ne ole tilastollisesti merkitseviä ( $\mathrm{p}>$ 0,05). Kaikkiin itäisiin paikannusryhmiin ("itä", "savo", "karjalan kieli", "kaakko") perusopinto-opiskelijoiden vastauksia sijoittui suhteellisesti hieman enemmän kuin aineopintovaiheen opiskelijoiden. Vain pohjoisten murteiden kohdalla ero on päinvastainen. Tuloksista voi päätellä, että aineopintovaiheen opinnot eivät vielä välttämättä lisää tietoa karjalan kielestä. Esimerkiksi suomen murteiden tunnistustestissä (Palander \& Nupponen 2005: 42-45), jossa opiskelijaryhmä sai tunnistettavakseen joukon murrenäytteitä ennen suomen aluemurteita koskevaa opintojaksoa ja uudestaan kurssin suorittamisen jälkeen, tulokset eivät kaikilta osin parantuneet. 


\section{Eräät kielenpiirteet paikantamisen perusteena}

Tässä luvussa tarkastelemme lähemmin neljää karjalan kielelle ominaista äänteellistä piirrettä, jotka näyttävät aineiston perusteella vaikuttavan siihen, mistä vastaajien vaikutelmat "idästä", "savolaisuudesta", "karjalaisuudesta", "kaakkoisuudesta" tai "pohjoisuudesta" johtuvat. Tavallisten kielenkäyttäjien on todettu havaitsevan eniten juuri murteiden äänteellisiä eroja, harvemmin morfologisia piirteitä (Preston 1999: xxix; Mielikäinen \& Palander 2014b: 151-152, 239). Avovastausten tulkinta on vaatinut harkintaa, sillä vaikka vastaajat ovat suomen kielen opiskelijoita, suuri osa heistä on käyttänyt vastuksissaan kansanomaista metakieltä. Tulkinnassa on otettu huomioon se, mitä ennestään tiedetään suomalaisten metakielestä (Mielikäinen \& Palander 2014b). Laskelmat on tehty niin, että mukaan on otettu sekä kielenpiirteen sanallinen kuvailu että muistiin merkityt sanat tai muodot, joissa kyseinen kielenpiirre esiintyy. Opiskelijoiden käyttämää metakieltä käsittelemme yleisemmin viimeisessä alaluvussa.

Kielenpiirteiden maininnat on esitetty kootusti taulukossa 5. Taulukkoa luettaessa on pidettävä mielessä, että osa vastaajista teki merkintöjä useasta kielenpiirteestä ja monet myös esittivät useampia kuin yhden arvion puhujan kotipaikasta. Prosentit kertovat, kuinka suuri osa kutakin aluetta arvanneista vastaajista on kiinnittänyt huomiota kyseiseen piirteeseen.

TAULUкко 5. Eräät kielenpiirteet suhteessa paikannuksiin

\begin{tabular}{|l|r|c|c|c|c|c|c|c|c|c|c|}
\hline \multirow{2}{*}{ Murrepiirre } & \multicolumn{2}{|c|}{ Itä } & \multicolumn{2}{|c|}{ Savo } & \multicolumn{2}{|c|}{ Karjala } & \multicolumn{2}{|c|}{ Kaakko } & \multicolumn{2}{c|}{$\begin{array}{c}\text { Pohjoi- } \\
\text { nen }\end{array}$} & $\begin{array}{c}\text { Vas- } \\
\text { taajia }\end{array}$ \\
\cline { 2 - 13 } & f & \% & f & \% & f & \% & f & \% & f & \% & N \\
\hline Diftongiutuminen & 124 & 58,2 & 76 & 73,8 & 27 & 51,9 & 19 & 63,3 & 42 & 54,5 & 206 \\
\hline Liudennus & 46 & 21,6 & 16 & 15,5 & 14 & 26,9 & 14 & 46,7 & 8 & 10,4 & 58 \\
\hline $\begin{array}{l}\text { Sibilantit ja } \\
\text { affrikaatat }\end{array}$ & 83 & 39,0 & 14 & 13,6 & 28 & 53,8 & 9 & 30,0 & 28 & 36,4 & 110 \\
\hline Jälkitavujen $h$ & 40 & 18,8 & 18 & 17,5 & 12 & 23,1 & 2 & 6,7 & 33 & 42,9 & 72 \\
\hline Vastaajia & 213 & & 103 & & 52 & & 30 & & 77 & & \\
\hline
\end{tabular}




\subsection{Pitkän a:n ja ä:n diftongiutuminen}

Pitkien $a$ - ja $\ddot{a}$-vokaalien diftongiutuminen kuuluu sekä karjalan kieleen että useimpiin suomen itämurteisiin. Ilmiöillä on yhteinen historia, joka juontunee muinaiskarjalasta (Rapola 1966: 349-350). Savolaismurteissa pääpainollisten $a a$ - ja $\ddot{a} a$-vokaalien diftongiutumisvaiheet $a a>o a>u a$ ja ää > eä > iä näkyvät siten, että Pohjois- ja Etelä-Savossa, Savonlinnan seudulla ja Pohjois-Karjalan etelä- ja keskiosissa on päädytty asuihin $u a$, iä (mua, piä). Sen sijaan tätä ydinaluetta ympäröivällä vyöhykkeellä äänteenmuutos on vielä oa, eä -vaiheessa (moa, peä). (Kettunen 1940: 154) Jälkitavuissa diftongiutuminen on mainitulla ydinalueella johtanut monoftongiin oo tai ee (poikaa > poikoa > poikoo, leipää > leipeä > leipee) (Kettunen 1940 179). Karjalan kielessä diftongiutuminen on tyypillistä sekä ensi- että jälkitavuissa. Diftongin kvaliteetti vaihtelee: moa mua, kaloa kalua 'kalaa'; Raja-Karjalan murteissa on kummankin kehitysvaiheen edustusta. (Leskinen 1998: 379)

Aineistossa diftongiutuminen oli yleisesti havaittu piirre: yhteensä 206 vastaajaa oli merkinnyt vastaukseensa diftongillisia muotoja ja/tai kommentoinut ilmiötä jollain tavoin. Taulukko 5 osoittaa, että piirre kytkeytyy vastauksissa erityisesti "Savoon" (74 \%) mutta myös laajemmin Itä-Suomeen ("itä" 58 \%, "Karjala” 52 \% ja "kaakko" 63 \%). Tulos noudattelee aikaisemman tutkimuksen havaintoja: suomen murteissa diftongiutuminen yhdistetään yleisesti savolaismurteisiin, ja se on savolaismurteiden tunnetuimpia piirteitä (Mielikäinen \& Palander 2014b: 169-171). Yllättävää testiaineistossa on diftongiutumisen suuri osuus (55\%) myös "pohjoista" veikanneissa vastauksissa; tämän selittää todennäköisesti se, että varsin usein samassa vastauksessa viitattiin sekä "pohjoiseen" että "savoon", "itään" tai "karjalaan", ja diftongiutuminen liittyy luultavasti jälkimmäisiin vaihtoehtoihin.

Näytteessä diftongiutumista esiintyy sekä ensitavussa (pitkäm matkam piässä, paikam piältä, hoǎšsttih) että jälkitavuissa (varaštoa, pahempoa). Kaikkia näitä muotoja oli merkitty opiskelijoiden vastauksiin, vaikkakin jälkitavuissa ilmiöön oli kiinnitetty huomiota selvästi 
harvemmin (49 vastaajaa). Vastauksiin oli kirjattu jonkin verran jotakuinkin oikein kuultuja muotoja, mutta usein merkinnät poikkesivat kielentutkijan litteraatiosta: piäällä, pijälle, piellä, pjäällä; huastettu; varastuo, varastoo, varastua, pahempua. Ilmiön kuvailussa vastaajat käyttivät sekä kielitieteen terminologiaa että kansanomaista metakieltä. Osa vastaajista käytti termejä diftongi tai diftongiutuminen (esimerkki 3), mutta termien käyttö oli usein horjuvaa, epämääräistä tai jopa virheellistä (esimerkki 4).

(3) kaksoisvokaalit muuttuneet diftongeiksi | pitkät loppuvokaalit diftongiutuneet | diftongeja pitkien vokaalien paikalla

(4) kaksoiskonsonantti > diftongi | pitkän vokaalin sijasta vokaaliyhtymä | diftongit avartuvat

Opiskelijoiden vastauksissa esiintyi runsaasti myös ei-kielitieteilijöille tyypillistä metakieltä (Mielikäinen \& Palander 2014b: 139, 169-170):

(5) viäntämistä | viäntää ja kiäntää | vokaalien vääntyminen savolaisittain

\subsection{Liudennus}

Sekä suomen itämurteissa että karjalan kielessä esiintyy dentaalikonsonanttien $n, t, s, l$ ja $r$ liudentuneisuutta, jolla tarkoitetaan konsonantin $j$-mäistä väriä. Suomen itämurteissa liudennuksen on aiheuttanut konsonanttia seuraava $i$ tai $j$. Kun sananloppuinen $i$ on laajalla loppuheittoalueella kadonnut, liudennus on jäänyt konsonanttiin edustamaan $i: t a ̈$ $\left(o l^{\prime} i>o l^{\prime}\right)$. Liudennus on kuulunut suurimpaan osaan savolaismurteita sekä kaakkoismurteisiin. (Kettunen 1940: 175) Karjalassa liudennusta esiintyy enemmän kuin suomen murteissa: paitsi sanansisäinen, myös sananalkuinen dentaalikonsonantti voi liudentua etuvokaalin edellä, ja liudennus koskee myös alkuperäisgeminaattoja ja konsonanttiyhtymiä (niiska, neuvo, rat't'i, kal'l'ivo, riśt'i). Konsonantti voi liudentua myös takavokaalin edellä (ńokka, ńapa). (Leskinen 1998: 379) Liudennus on venäjän vaikutusta (Turunen 1959: 194), ja karjalan kielessä tuo vaikutus on ollut laajempaa kuin suomessa. 
Kuuntelutestin näytteessä liudennusta esiintyy runsaasti, mutta siihen on vastauksissa kiinnitetty huomiota paljon harvemmin kuin diftongiutumiseen (58 vastaajaa). Taulukon 5 perusteella liudennus on mainittu erityisesti niissä vastauksissa, joissa kielennäyte on sijoitettu "kaakkoon" (47 \%), ja myös "karjalaa" ja "itää" veikanneilla on mainintoja liudennuksesta (27 \% ja $22 \%$ ). "Savoon" sijoittaneista liudennukseen on kiinnittänyt huomiota $16 \%$ ja "pohjoiseen" sijoittaneista vain $10 \%$.

Nykyisissä suomen itämurteissa liudennus on väistyvä piirre (esim. Nuolijärvi \& Sorjonen 2005: 95; Palander 2016: 99). Tavalliset kielenkäyttäjät eivät yleensä mainitse sitä kuvaillessaan aluemurteita, mutta kun sitä kommentoidaan, se liitetään juuri savolaismurteisiin (Mielikäinen \& Palander 2014b: 179-180; Nupponen 2011: 101). Tässä suhteessa kuuntelutestin vastaajat poikkeavat aikaisemmasta tutkimuksesta, sillä ne vastaajat, jotka olivat huomanneet liudennuksen, tuntuivat pitävän ilmiötä enemmän kaakkoismurteiden kuin savolaismurteiden piirteenä. Lisäksi liudennusta pidetään aineistossa melko epäsuomalaisena piirteenä, joka kytketään usein venäjän kieleen (esimerkki 6). Vain yksi vastaaja yhdisti liudennuksen eksplisiittisesti karjalan kieleen (esimerkki 7). Tämä tulos ei ole siinä mielessä yllätys, että venäjän kieli (tai venäläisten puhuma suomen kieli) on epäilemättä nykysuomalaisille paljon tutumpi ja useammin kuultu kielimuoto kuin karjala.

(6) venäläistyylinen nj-äänne | äänsi j-äänteen kuin suomea puhuvalla venäläisellä on tapana | venäläinen nuotti

(7) nasaaliäänteissä on jotain karjalaista, j-mäisiä kaikuja

Liudennukselle ei ole suomen ortografiassa omaa merkkiään, mutta j-kirjaimen käyttö on suomen murretta kirjoitettaessa alkanut vakiintua yleisesti tunnetuksi liudennuksen merkintätavaksi (Mielikäinen 2004: 512-514). Myös kuuntelutestin vastaajat käyttivät j-kirjainta muotoja jäljitellessään: olj, semmonje, hjänen mjielestä, njiin, njimi. Liudennusta merkitsevää tarketta käytti yksi vastaaja $\left(o l^{\prime}\right)$. Ilmiöstä muutamat opiskelijat käyttivät kielitieteen termejä (esimerkki 8), mutta tavallisempaa oli kuitenkin luonnehtia liudennusta muulla tavoin (esimerkki 9). Tässäkin 
tapauksessa opiskelijoiden sananvalinnat muistuttavat ei-kielitieteilijöiden käyttämää metakieltä (Mielikäinen \& Palander 2014a s.v. pehmeä; Palander 2015: 52).

(8) liudentuneita äänteitä | 1 monesti palataalisempi, j:mäinen | liudentunut $1 \mid$ palatalisaatio

(9) j-äänne tulee myös ilmi usein käyttää pehmeitä äänteitä | ääntyi j paikoissa, joissa en itse sitä sinne tunge | paljon j:itä sanojen välissä ja 1 pehmeämpi kuin normisti

\subsection{Sibilantit ja affrikaatat}

Karjalan kielelle ovat ominaisia soinnillinen $s$ (esim. pezen), suhusibilantit š ja $\check{z}$ (koški, žiivattu 'elukka, lehmä) sekä affrikaatta č (kaččuo : kačon; Leskinen 1998: 378-379). Nämä äänteet puuttuvat suomesta, ja erityisesti affrikaatta kuuluu piirteisiin, joilla rajakarjalaistaustaiset itsekin luonnehtivat karjalan kieltä (Palander 2015: 49, 51-52). Käsittelemme sibilantit ja affrikaatan samassa luvussa, koska äänteet muistuttavat toisiaan ja testiin osallistuneiden vastauksista on osin vaikea päätellä, kumpaa on tarkoitettu. Kuuntelunäytteessä š-äännettä esiintyi runsaasti (mihin saattoi osaksi vaikuttaa myös puhujan ikä), ja affrikaatta oli käytössä kerran, helposti tunnistettavassa sanassa iče. On lisäksi mahdollista, että sibilanttien havaitsemiseen ovat vaikuttaneet näytteessä esiintyvät $s t$ - ja $s k$-yhtymien heikkoasteiset ss-variantit (en muissa, ei kässe).

Testiin osallistuneista kaikkiaan 110 vastaajaa oli joko merkinnyt vastauksiinsa $\check{s}:$ n tai affrikaatan sisältäviä muotoja tai kommentoinut näitä äänteitä; määrä on kaksinkertainen liudennuksen havainneisiin verrattuna. Taulukosta 5 selviää, että näihin äänteisiin liittyvät havainnot ovat yleisimpiä niillä informanteilla, jotka ovat sijoittaneet näytteen "Karjalaan" (noin 54 \%). "Itään" sijoittaneilla osuus on 39 \%, kaakkoon sijoittaneilla 30 \% mutta "Savoon" sijoittaneilla vain noin $14 \%$. Yllättäen niillä vastaajilla, jotka pitivät näytettä "pohjoisena”, sibilantteihin ja affrikaattoihin viittaavia mainintoja on 35 \%:lla, mutta tässä on jälleen muistettava, että melko suuri osa vastaajista mainitsi puhujan mahdollisena 
kotipaikkana sekä pohjoisen että itäisen ilmansuunnan. Yksi vastaaja yhdistää affrikaatan karjalan kieleen (esimerkki 10), mutta tavallisempaa on liittää erikoiset sibilantit ja affrikaatat venäjän kieleen (esimerkki 11).

(10) ičče karjalan kielessä esiintyvä ts

(11) jotkut äänteet kuulostavat hieman venäläisiltä, esim. s- sanassa itše | s suhahtelee välillä, kuten venäjän kielessä | kuulostaa slaavilaiselta $\rightarrow$ pehmentää s-äänteitä

Suhusibilantteja ja affrikaattaa on osallistujien vastauksissa merkitty varsin kirjavasti, mikä osittain johtunee myös kuulohavaintojen erilaisuudesta. Suhu-s:n merkkiä š käytetään jonkin verran suomeen tulleissa lainasanoissa, ja monet vastaajat valitsivat sen (muišša, käšše, šitä, takaš, peššä). Toisaalta käytössä oli myös kirjainyhdistelmä sh (takashi, muissha, kässhe, shitä, olish, voijshi). Affrikaatan merkkinä kaksi vastaaja käytti karjalan kielen ortografian merkkiä $\check{c}$ (iť̌e, ičče), ja eräs toinen merkitsi affrikaatan suhu-s:n foneettisella merkillä (itfe). Muuten affrikaattaa jäljiteltiin erilaisilla kirjain- ja merkkiyhdistelmillä (itshe, ithe, itz'e, ize, itsche).

Sibilantteihin ja affrikaattoihin on aineistossa osittain viitattu kielitieteen termein tai niitä tavoitellen (esimerkki 12). Tavallinen on ilmaus suhu-s (tai suhuässä), joka on käytössä sekä kielitieteessä että arkikielessä. Yleisiä ovat myös kuvaustavat, jotka muistuttavat ei-kielitieteilijöiden metakieltä (ks. esimerkki 13; vrt. Mielikäinen \& Palander 2014b: 220-221; Palander 2015: 52).

(12) samoin [s] on [š]-kuuloinen | affrikaattaäänne | ts-yhtymä edustuu affrikaattana | spirantit joita ei esiinny suomen yleiskielessä

(13) s suhisee, kuulostaa vieraalle | puhe välillä ihan kuin puuroutuisi sössötykseksi | s oli aika löysä | joissakin sanoissa paksumpi s

\subsection{Jälkitavujen $h$}

Jälkitavujen $h$ on karjalassa säilynyt kaikissa asemissa (esim. kintahat, nälgähine, patah, tullah, juotih, veneh : venehtä; Leskinen 1998: 378379). Kielennäytteessä jälkitavujen $h$ esiintyy eräissä passiivin muodoissa 
(käytih, sanottih, hoaššettih), MA-infinitiivin illatiivissa (sanomah) ja illatiivimuodossa mukah: kaikissa tapauksissa $h$ on muodon lopussa. Jälkitavujen $h$ :n edustus erottaa karjalaa suomesta, sillä suomessa $h$ on sekä yleiskielessä että valtaosassa murteita kadonnut painottoman tavun jäljestä (kintaat, $p a(t) t a a n$, juotiin, vene $e^{x}$ : venettä). Jälkitavujen säilynyt $h$ on suomessa tyypillinen pohjalaismurteiden piirre; eteläpohjalaismurteissa $h$ :ta tavataan vokaalien välissä (otetahan) tai sisäheittomuodoissa (menhän). Metateettista h:ta (koulhuun, menehmän) on erityisesti peräpohjalaismurteissa. (Kettunen 1940: 107-108, 110; Rapola 1966: 253-264) Tässä suhteessa karjala on siis lähempänä pohjalaismurteita kuin suomen itämurteita.

Kuuntelutestiaineistossa jälkitavujen $h$ on otettu esiin kaikkiaan 72 vastauksessa, jälleen joko kirjoittaen muistiin $h$ :llisia muotoja tai kommentoiden ilmiötä muulla tavoin. Vastausten jakauma (ks. taulukkoa 5) osoittaa selvästi, että piirre on mielletty pohjoiseksi. Niistä vastaajista, jotka sijoittivat kielennäytteen "pohjoiseen", $43 \%$ on kiinnittänyt huomiota $h$ :hon. "Karjalaa" veikanneista $h: n$ on maininnut $23 \%$, ja muissa paikannuksissa osuudet ovat vielä pienemmät ("itä" $19 \%$, "Savo" $18 \%$ ja "kaakko" $7 \%$ ). Tulokset ovat yhteensopivia sen kanssa, mitä entuudestaan tiedetään suomalaisten murrenäkemyksistä: ei-lingvistit yhdistävät jälkitavujen $h$ :n yhtäältä Etelä-Pohjanmaan mutta toisaalta etenkin Peräpohjolan eli "Lapin" murteisiin. $h$ on peräpohjalaismurteiden ylivoimaisesti tunnetuin piirre. (Palander 2011: 82-83, 92-94; Mielikäinen \& Palander 2014b: 160-162; ks. myös Vaattovaara 2009: 71-72) Tässä valossa ei ole yllättävää, että tämä karjalan kielelle ominainen piirre on testivastaajien joukossa tulkittukin pohjoisen murteiden ominaisuudeksi. Vaikuttaa myös siltä, että nimenomaan jälkitavujen $h$ on aiheuttanut "pohjoiseen" osuvien paikannusten yllättävän suuren osuuden (ks. lukua 3.1).

Jälkitavujen $h$ :hon viittaavat aineiston vastauksissa selvästi ainakin vastaajien muistiin kirjaamat $h$ :lliset muodot kuten sanomaha, sanomahen ja haastettihen. Huomionarvoista on, että yksikään vastaaja ei merkinnyt muistiin karjalan kielelle ominaista $h$-loppuista muotoa, vaan 
muotoja on täydennetty suomen mukaisella $V(n)$-aineksella. Tämäkin viittaa siihen, että muodot on käsitetty suomen murteiden mukaisiksi. Toisaalta $h$-äännettä on kirjattu vastauksissa moniin sellaisiin sana-asemiin, joissa sitä ei näytteessä esiinny: paehkam piältä, järkhiää, mithää, jälkheen. Kolme viimemainittua muotoa olisivat mahdollisia suomen peräpohjalaismurteissa, mutta paehkam piältä muistuttaa suomalaisten hyperdialektaalisia murrejäljittelyjä (jänkhä, joikhata; Palander 2011: 92-93). $h$-äännettä kommentoineet vastaajat ovat usein kirjanneet myös sellaisia muotoja kuin muisha tai thoi shen ithe, joissa suhu-s ja affrikaatta ovat ilmeisesti luoneet vaikutelmaa $h$-äänteen käytöstä (ks. lukua 4.3).

Jälkitavujen $h$ :n kuvailussa ei ole kertaakaan käytetty varsinaista kielitieteellistä nimitystä. Muutamat vastaajat kuvailevat ilmiötä käyttämällä muuta kielitieteen terminologiaa (esimerkki 14), mutta jälleen on yleisesti käytetty kansanomaisempia kuvailutapoja (esimerkki 15). Kaksi vastaajaa mukailee peräpohjalaista ilmausta puhua h:n päältä (esimerkki 16; Mielikäinen \& Palander 2014b: 148-149). Kokonaisuudessaan aineistosta tulee vaikutelma, että suomesta (yleiskielestä ja useimmista murteista) poikkeava $h$-äänne yhdistetään sellaisenaan peräpohjalaismurteisiin, mutta vastaajilla on vain hämärä käsitys siitä, millaisissa muodoissa $h$ todellisuudessa pohjoisessa esiintyy.

(14) ylimääräinen h vokaalien välissä | H-äänne joissain sanoissa

(15) runsaasti h-kirjainta sanoissa | h-kirjainta ilmestyy sanojen keskelle | tunkee h:ta sanojen alkuun, keskelle ja loppuun

(16) puhuu ns. h:n päälle | välillä kuulen puhuttavan "H:n piältä"

\subsection{Opiskelijoiden käyttämä metakieli}

Kuuntelutestin informanteista noin kaksi kolmasosaa oli perusopintovaiheen eli enimmäkseen 1. vuoden opiskelijoita; sivuaineopiskelijoilla on voinut olla jo muutama vuosi jonkin muun aineen opintoja takanaan. Kolmasosa informanteista oli suorittamassa suomen aineopintoja. Testivastauksista näkyy, että yliopistotasoinen kielitieteellinen koulutus on jo vaikuttanut kielenilmiöistä käytettyyn metakieleen: 
perusopinto-opiskelijoiden ryhmässäkin esiintyi oikeissa yhteyksissään sellaisia lingvistisiä termejä, kuten liudennus ja palatalisaatio, affrikaatta, assimilaatio, diftongiutuminen, yleisgeminaatio, d:n kato ja intonaatio, joista osan tuntevat varsinaiset maallikotkin (Mielikäinen \& Palander 2014b: 119-131). Lisäksi eräät yliopisto-opiskelijat merkitsevät äänteitä kielitieteen konventioiden mukaisesti (esim. $d \rightarrow \emptyset$; $\check{s}$; ; ol'; puolivokaali /j/; ss oli kuin [sh]). Termejä käytetään kuitenkin toisinaan eri merkityksessä kuin kielitieteessä: perusopintovaiheen opiskelijoiden vastauksissa mainittiin $\mathrm{mm}$. vokaalien liudentuminen ja diftongien avartuminen, jolla tarkoitettiin ensitavun aa:n ja ää:n diftongiutumista (piälle). Varttuneemmatkin opiskelijat saattoivat pitää diftongia vokaaliyhtymänä (sanassa piässä) ja nimittää äänteitä kirjaimiksi.

Opintojen vaiheesta riippumatta vastauksissa olikin runsaasti tavallisille maallikoille ominaista metakieltä (ks. Mielikäinen \& Palander 2014b: 131-150; Nupponen 2011: 103-108). Perusopinto-opiskelijoiden metakieltä havainnollistavat esimerkki (17) ja aineopintovaiheen opiskelijoiden käyttämää kieltä esimerkki (18).

(17) voimakas s-kirjaimen käyttö | h-kirjaimen lisääminen | sanoja [---] jatkettiin | vokaaleiden vähentäminen | venytetyt vokaalit | puheessa oli toisiinsa sulautuvia, liukuvia vokaaleja kuten Savon murteessa | erilaisia äänenpainoja ja ilmauksia

(18) vähemmän lyhennettyjä sanoja | loppunieltyjä tavuja | kirjaimia "pudonnut pois" | vokaalien vääntyminen savolaisittain | ässät olivat sössöttäviä | D-kirjain kadonnut

Vastausten perusteella voi sanoa kokoavasti, että vuoden tai kahden ero opinnoissa ei vielä ratkaisevasti näy kielenpiirteiden kuvauksissa.

\section{Kokoava katsaus}

Tunnistustesti osoitti, että näytteen rajakarjalainen kielimuoto oli monille opiskelijoille täysin vierasta. Kysymykseen "Mistä näytteen puhuja on kotoisin?" oli yleensä vastattu jotakin, mutta näytteen kielimuotoa koskevaan kysymykseen oli noin 20 lomakkeessa jätetty 
kokonaan vastaamatta, ja saman verran tässä kohtaa oli "en tiedä" -vastauksia. Vaikka murteen paikantaminen oli vaikeaa, osa kuitenkin piti kieltä tuttuna, ja neljä vastaajaa viittasi oman isoäitinsä kieleen:

(19) Muuten puhe on hyvin tuttua, kuulostaa lähes samalta kuin mummoni puhe. | Täysin ymmärrettävää, oma mummo puhui hieman vastaavasti.

Näytteen itäisyys tunnistettiin kaikkiaan varsin hyvin, vaikkakin monet piirteet liitettiin enemmän savolaismurteisiin kuin karjalaan. Lisäksi vastauksissa oli "kaakkoon" suuntautuvia arvauksia, mikä selittyy luonnollisesti siitä, että itämurteilla ja karjalalla on yhteinen alkuperä ja kielimuodoissa on toisiaan muistuttavia piirteitä. Hieman yllättävästi monet vastaajat sijoittivat näytteen peräpohjalaisalueelle. Tähän oli ilmeisesti syynä erityisesti jälkitavujen $h$, joka on yleisesti tunnettu peräpohjalaisuus.

Niillä vastaajilla, jotka tunnistivat karjalan kielen, on nähtävästi ollut jonkinasteista tietoa karjalasta. Siihen tuntuisivat viittaavan ainakin varieteetista käytetyt nimitykset vienankarjala ja karjalan kieli. Eräistä näytteen kuvauksista paljastuu karjalan kielen fonetiikan tuntemusta:

(20) Karjalasta? Alunperin (kuuluu pieniä kaikuja, kuten suhu-s ja ängäännettä), nykyisin voisi asua esim. Ilomantsissa tai muualla ItäSuomessa.

Tarkastelimme testistä kaikkiaan kolmen taustatekijän, vastaajan murretaustan, yliopiston sekä suomen kielen opintojen vaiheen, vaikutusta näytteen tunnistamiseen. Tilastollisesti vahvimmin eroihin vaikutti vastaajan kotiyliopisto (erittäin merkitsevästi, $\mathrm{p}<0,01$ ) ja toiseksi vahvimmin vastaajan oma murretausta (merkitsevästi, $\mathrm{p}<0,05$ ). Sen sijaan opintojen vaiheella ei ollut vaikutusta testituloksiin. Näytteen tunnistivat parhaiten taustaltaan itäsuomalaiset, erityisesti Itä-Suomen yliopiston opiskelijat. Maantieteellinen läheisyys Raja-Karjalan kanssa sekä yliopiston itärajaa korostava profiloituminen näkyvät siis tuloksissa.

Monissa vastauksissa tuli ilmi näytteessä olevan varieteetin vieraus tai erilaisuus. Se nähtävästi osaltaan vaikutti myös näytteen 
paikantamiseen: näyte sijoitettiin kauas omalta kotiseudulta. Niinpä monet länsimurteiset arvioivat näytteen edustavan itäistä tai pohjoista kielimuotoa ja pohjoismurteiset taas sijoittivat sen usein itään. Itämurteisista monet tunnistivat murteen itäisyyden, mutta kuitenkin osa heistä sijoitti sen pohjoiseen.

Kaikkiaan testi osoitti oikeaksi sen ennakkokäsityksen, että karjalan kieli on heikosti tunnettu kielimuoto. Vaikka informantteina olivat opintojensa alkuvaiheen suomen kielen opiskelijat, joilla olettaisi jo olevan ei-lingvistejä enemmän tietoa suomen lähisukukielistäkin, tulos vastannee pitkälti tavallisten maallikkonuorten mielikuvia. Valtaosa testiin osallistuneista oli 1980-1990-luvuilla syntyneitä, joiden lapsuusaikana karjalan kieli oli jo assimiloitunut suomeen. Vastaajien käyttämästä metakielestä voi lisäksi päätellä, että vuoden tai parin mittainen korkeakoulutasoinen opiskelujakso ei vielä ole ratkaisevasti muuttanut tapaa puhua kielestä.

\section{Kiitokset}

Kiitämme lämpimästi Markus Hamusta, Anna Kaikkosta, Niina Kunnasta, Tommi Kurkea, Hanna Lappalaista ja Liisa Mustanojaa kuuntelutestin järjestämisestä omissa yliopistoissaan. Kiitokset myös Maaret Räsäselle ja Susanna Taville, jotka tutkimusavustajina järjestivät testin tulokset Excel-tietokantaan, ja Jukka Mäkisalolle, joka tilastolingvistiikan asiantuntijana laski merkitsevyydet.

\section{Lähteet}

Jeskanen, Matti 2005. Karjalan kieli ja karjalankieliset Suomessa ['Karelian language and speakers of Karelian in Finland']. - Marjatta Palander, AnneMaria Nupponen (Toim.), Monenlaiset karjalaiset. Suomen karjalaisten kielellinen identiteetti. Studia Carelica Humanistica 20. Joensuu: Joensuun yliopiston humanistinen tiedekunta, 215-285.

Kettunen, Lauri 1940. Suomen murteet III A. Murrekartasto ['Finnish dialects. Dialect chart of Finnish']. Suomalaisen Kirjallisuuden Seuran toimituksia 188. Helsinki: SKS. 
Koivisto, Vesa (tulossa). Border Karelian dialects: A diffuse variety of Karelian.

Kokko, Susanna 2010. Kahden ikäryhmän raahelaisten käsityksiä suomen murteista. Pro gradu -tutkielma. Helsingin yliopisto, suomen kieli. http://urn. fi/URN:NBN:fi-fe201006152031

Laakso, Johanna, Anneli Sarhimaa, Sia Spiliopoulou Åkermark, Reetta Toivanen 2016. Towards Openly Multilingual Policies and Practices. Assessing Minority Language Maintenance Across Europe. Linguistic Diversity and Language Rights. Bristol: Multilingual Matters.

Laurila, Anna-Leena 2008. Mielteitä omasta murteesta. Kansanlingvistinen tutkimus Lammilta. Pro gradu -tutkielma. Helsingin yliopisto, suomen kieli.

Leino, Antti, Saara Hyvönen, Marko Salmenkivi 2006. Mitä murteita suomessa onkaan? Murresanaston levikin kvantitatiivista analyysiä ['A quantitative analysis of the distribution of dialect words']. - Virittäjä 110, 26-45.

Leskinen, Heikki 1998. Karjala ja karjalaiset kielentutkimuksen näkökulmasta. Pekka Nevalainen, Hannes Sihvo (Toim.), Karjala. Historia, kansa, kulttuuri. Suomalaisen Kirjallisuuden Seuran toimituksia 705. Helsinki: SKS, 352-382.

Mielikäinen, Aila 2004. Liudennus murretutkimuksissa ja savolaismurteisessa kirjallisuudessa ['Palatalisation in dialect research and in literature written in the Savo dialect']. - Virittäjä 108, 508-530.

Mielikäinen, Aila, Marjatta Palander 2002. Suomalaisten murreasenteista ['Finnish attitudes to dialects']. - Sananjalka 44, 87-110.

Mielikäinen, Aila, Marjatta Palander 2014a. Miten murteista puhutaan. Kansanlingvistinen sanakirja. Jyväskylän yliopisto, Kielikampus. http://kielikampus.jyu.fi/mitenmurteistapuhutaan/ (15.3.2017).

Mielikäinen, Aila, Marjatta Palander 2014b. Miten suomalaiset puhuvat murteista? ['How Finns speak about dialects']. Kansanlingvistinen tutkimus metakielestä. Suomi 203. Helsinki: SKS.

Mikkola, Laura 2011. Murteellisuus, maalaisuus ja miellyttävyys helsinkiläisten kuulemana: monimenetelmäinen tutkimus lukiolaisten kieliasenteista. Pro gradu -tutkielma. Helsingin yliopisto, suomen kieli. http://urn.fi/ URN:NBN:fi-fe201107221909

Niedzielski, Nancy A. 1999. The effect of social information on the perception of sociolinguistic variables. - Journal of Language and Social Psychology 18 (1), 62-85. https://doi.org/10.1177/0261927X99018001005

Niedzielski, Nancy A., Dennis R. Preston 2000. Folk Linguistics. Trends in Linguistics. Studies and Monographs 122. Berlin: Mouton de Gruyter. 
Nuolijärvi, Pirkko, Marja-Leena Sorjonen 2005. Miten kuvata muutosta? Puhutun kielen tutkimuksen lähtökohtia murteenseuruuhankkeen pohjalta. Kotimaisten kielten tutkimuskeskuksen julkaisuja 133. Helsinki: Kotimaisten kielten tutkimuskeskus.

Nupponen, Anne-Maria 2011. "Savon murre" savolaiskorvin. Kansa murteen havainnoijana ['The "Savo dialect" according to Savo residents. Folk perceptions of dialectal speech]. Publications of the University of Eastern Finland. Dissertations in Education, Humanities, and Theology 11. Joensuu: University of Eastern Finland. http://urn.fi/URN:ISBN:978-952-61-0354-9

Palander, Marjatta 2001. Kansan käsityksistä lingvistiikkaa. Kirja-arvio ['Review: Preston, Dennis R. (Ed.), Handbook of perceptual dialectology']. - Virittäjä 104, 147-151.

Palander, Marjatta 2011. Itä- ja eteläsuomalaisten murrekäsitykset. Suomi 200. Helsinki: SKS.

Palander, Marjatta 2015. Rajakarjalaistaustaisten ja muiden suomalaisten mielikuvia karjalasta ['How Border Karelians and other Finns view Karelian']. Virittäjä 119, 34-66.

Palander, Marjatta 2016. Savolaismurteen muutos: kahden sukupolven seitsenvuotiaiden puhekieli ['Change in the Finnish Savo dialects: the spoken language of the 7-year-olds of two generations']. - Sananjalka 58, 89-111.

Palander, Marjatta, Anne-Maria Nupponen 2005. Karjalaisten "karjala" ['What is Karelian for Karelians']. - Marjatta Palander, Anne-Maria Nupponen (Toim.), Monenlaiset karjalaiset. Suomen karjalaisten kielellinen identiteetti. Studia Carelica Humanistica 20. Joensuu: Joensuun yliopisto, humanistinen tiedekunta, 15-55.

Paunonen, Heikki 1991. Till en ny indelning av de finska dialekterna. - FennoUgrica Suecana 10, 75-95.

Paunonen, Heikki 2006. Vähemmistökielestä varioivaksi valtakieleksi. - Kaisu Juusela, Katariina Nisula (Toim.), Helsinki kieliyhteisönä. Helsinki: Helsingin yliopisto, Suomen kielen ja kotimaisen kirjallisuuden laitos, 13-99.

Preston, Dennis R. 1999. Introduction. - Dennis R. Preston (Ed.), Handbook of Perceptional Dialectology. Volume 1. Amsterdam: John Benjamins, xxiiixl. https://doi.org/10.1075/z.hpd1

Pyöli, Raija 2013. Rajakarjalaiset ja muuttuva identiteetti ['Border Karelians and change of the identity']. - Pekka Suutari (Toim.), Karjala-kuvaa rakentamassa. Suomalaisen Kirjallisuuden Seuran toimituksia 1389. Helsinki: SKS, 159-181. 
Rapola, Martti 1966. Suomen kielen äännehistorian luennot. Suomalaisen Kirjallisuuden Seuran toimituksia 283. Helsinki: SKS.

Saaristo, Heidi 2015. Mitä diftongien avartumisesta ajatellaan? Kielenkäyttäjien mielikuvia. Pro gradu -tutkielma. Helsingin yliopisto, suomen kieli. http:// urn.fi/URN:NBN:fi-fe2015061110215

Sarhimaa, Anneli 2016. Karelian in Finland. ELDIA Case-Specific Report. Studies in European Language Diversity 27. https://fedora.phaidra.univie.ac.at/ fedora/get/o:471733/bdef:Content/get (12.12.2016).

Turunen, Aimo 1959. Itäisten savolaismurteiden äännehistoria. Suomalaisen Kirjallisuuden Seuran toimituksia 253. Helsinki: SKS.

Turunen, Aimo 1982. Raja-Karjalan murteet ['Dialects of the Border Karelian']. Karjala 2. Karjalan maisema ja luonto. Hämeenlinna: Arvi A. Karisto Oy, 65-89.

Vaattovaara, Johanna 2005. Lisää lingvistiikkaa kansan käsityksistä ['Review: Handbook of Perceptual Dialectology. 2. Amsterdam, 2002']. - Virittäjä $109,466-475$.

Vaattovaara, Johanna 2009. Meän tapa puhua. Tornionlaakso pellolaisnuorten subjektiivisena paikkana ja murrealueena. Helsinki: SKS.

Vaattovaara, Johanna 2013. On the dynamics of non-linguists' dialect perceptions - the perceived spatiality of /s/ in Finnish. - Monika Reif, Justyna A. Robinson, Martin Pütz (Eds.), Variation in Language and Language Use: Linguistic, Socio-Cultural and Cognitive Perspectives. Duisburg Papers on Research in Language and Culture 96. Frankfurt am Main: Peter Lang, 134-163.

Vilhula, Kaisa 2012. Pääkaupunkilainen puhekieli kahden paikallisen ryhmän kuulemana ja keskustelemana. Pro gradu -tutkielma. Helsingin yliopisto, suomen kieli. http://urn.fi/URN:NBN:fi-fe201207026147

\section{Helka Riionheimo}

Itä-Suomen yliopiston humanistinen osasto, suomen kieli ja kulttuuritieteet

PL 111

FI-80101 Joensuu, Finland

helka.riionheimo@uef.fi

\section{Marjatta Palander}

Itä-Suomen yliopiston humanistinen osasto, suomen kieli ja kulttuuritieteet

PL 111

FI-80101 Joensuu, Finland

marjatta.palander@uef.fi 


\title{
Border Karelian recognition test: University students of Finnish language as observers
}

\author{
HELKA RIIONHEIMO, \\ MARJATTA PALANDER \\ University of Eastern Finland
}

The study uses a folk-linguistic recognition task to investigate how well students of Finnish language at Finnish universities recognise a sample of Border Karelian dialect. The Karelian language (once spoken in the Border Karelia region in the easternmost corner of pre-war Finland) is severely endangered and most Finns have never heard Karelian spoken publicly. The test confirms the presumption that the Border Karelian dialect is not familiar to university students. The respondents were allowed to make one or more guesses about the origin of the test sample. More than a half of the 337 respondents placed the sample in the eastern parts of Finland, one third in the Savo region, a fifth in Northern Finland and a tenth in South-Eastern Finland. About 15\% of the students recognised the sample as Karelian; Karelian was best recognised by the students of the University of Eastern Finland. Some respondents commented on the foreignness of the sample and connected it with Russian in particular. The linguistic features frequently mentioned include the diphthongisation of $a a$ and $\ddot{a} \ddot{a}$, non-Finnish sibilants and the Karelian affricate, word-final $h$ and palatalised consonants; the respondents seemed to locate the speaker on the basis of these features. Even though the terminology used by the students proved to be partly different from the metalanguage of Finnish non-linguists, the linguistic descriptions also contained folk and colloquial expressions.

Keywords: recognition test; folk-linguistics; Border Karelian; Karelian; Finnish 